\title{
Okras (Abelmoschus Esculentus L. Moench) Drying Behaviour After Undergoing Blanching or Combined Dewatering-Impregnation-Soaking Process (DISP)/Blanching
}

\author{
Jiokap Nono Yvette ${ }^{1, *}$, Aseaku Jude Nkengbeza ${ }^{1}$, Desmorieux Helene ${ }^{2}$, Degraeve Pascal ${ }^{3}$, \\ Kamga Richard ${ }^{4}$ \\ ${ }^{1}$ University Institute of Technology (IUT) of the University of Ngaoundere, Department of Chemical Engineering and Environment, \\ Ngaoundere, Cameroon \\ ${ }^{2}$ Process Engineering and Automatic Laboratory of University Claude Bernard - Lyon, Villeurbanne Cedex, France \\ ${ }^{3}$ Food Processing Research Laboratory of Claude Bernard - Lyon 1 University, University Institute of Technology A Lyon 1 - Biological \\ Process Department, Technopole Alimentec - Rue Henri de Boissieu, Bourgen Bresse Cedex, France \\ ${ }^{4}$ National Advanced School of Agro-Industrial Sciences (ENSAI) of the University of Ngaoundere, Department of Applied Chemistry, \\ Ngaoundere, Cameroon
}

Email address:

jiokapnonoy@yahoo.fr (J. N. Yvette)

\section{To cite this article:}

Jiokap Nono Yvette, Aseaku Jude Nkengbeza, Desmorieux Helene, Degraeve Pascal, Kamga Richard. Okras (Abelmoschus Esculentus L. Moench) Drying Behaviour After Undergoing Blanching or Combined Dewatering-Impregnation-Soaking Process (DISP)/Blanching. International Journal of Science, Technology and Society. Vol. 3, No. 5, 2015, pp. 243-253. doi: 10.11648/j.ijsts.20150305.14

\begin{abstract}
Traditional (solar) drying of okra fruits (Abelmoschus esculentus L. Moench) often gives products of poor storage quality, short shelf life and unpleasant sight. This study assesses the suitability of a dewatering-impregnationsoaking process (DISP) and blanching prior to drying as a means of improving the stability and the appearance of the dried okras. The DISP/Blanching pre-treatment involved immersing whole okra fruits for 12 hrs in a warm concentrated osmotic solution (made of $\mathrm{NaCl}$, ascorbic acid, citric acid and "kanwa") that was progressively cooled from $85^{\circ} \mathrm{C}$ to room temperature $\left(\sim 24^{\circ} \mathrm{C}\right)$, before drying at $40^{\circ} \mathrm{C}$. Compared to simple blanching, the DISP/Blanching pre-treatment yielded dry products that were better appreciated both to the touch and to the sight. The combined DISP/Blanching and drying process gave averages of $(78.1 \pm 3.6) \%$ weight reduction, $(9.1 \pm 0.5) \%$ solute gain and $(87.2 \pm 4.0) \%$ water loss. The total water loss was due at $35.6 \%$ to the DISP/blanching pre-treatment and at $64.4 \%$ to the further drying process. The results obtained here demonstrate the possibility of improving the storage quality of dried okra through the combined DISP/Blanching pre-treatment, reducing post-harvest losses and improving the market quality of dry products. This treatment could be applied industrially to enhance the presentation of tropical vegetables in international markets.
\end{abstract}

Keywords: Okra, Dewatering-Impregnation-Soaking Process (DISP), Blanching, Air Drying, Kinetics, Quality

\section{Introduction}

The okra plant (Abelmoschus esculentus L. Moench) is a tropical dicotyledonous plant grown throughout the tropics and warm temperate regions for its immature pod used as vegetable, food ingredient, as well as a traditional medicine [1-3]. Okra is not common in most European countries [4] whereas in tropical countries like Cameroon, cultivation of the crop represents an important agricultural and economic activity $[3,5]$. Although, scientific studies on okra began in the first half of the $20^{\text {th }}$ century, much of these were dedicated to some of its diseases like the okra virus [6], the rheology and emulsifying properties of its hydrocolloids [7, 8], the medicinal properties of its mucilage [9], the feasibility of using okra gum as fat replacement in food industries [10, 11] or okra as a rich source of high quality edible fat and protein $[4,12,13$,$] . Nowadays, research works are mostly$ directed towards improving okra farming productivity and yields $[3,14,15,16]$, on quality attribute of the fresh and dried pods $[17,18]$ or on okra dryer design $[19,20]$. 
In Cameroon, okra is often conserved using traditional processing techniques like solar drying in the open. These techniques are however largely inappropriate during the rainy season when solar radiations are low, ambient air relative humidity is high and fruit production is at its peak, hence high post-harvest losses [3]. Furthermore, drying under this time-consuming conditions gives products with pathogenic microorganisms, impurities and a dark colour that reduce the market quality of the slice-dried or milled product [21-23].

Recent publications highlight the need to pre-treat (chemically or physically) fruits and vegetables prior to drying as a means of avoiding any significant structural changes and improve their reconstitution properties [24, 25], ensure maximum inhibition of enzymatic browning reactions and reduce their initial microbial count [26]. Notable amongst these, blanching and/or dewatering-impregnationsoaking process (DISP) generate superior quality marketable products that could be preserved for long [24, 27-31]. The presence of solutes like citric acid reduces the solution's $\mathrm{pH}$, while "Kanwa" and ascorbic acid serve as chlorophyll-fixing and folate-retention agents [32], improve the colour or the vitamin retention of processed fruits and vegetables and maintain their texture $[29,33,34]$.

In the light of similar research works, some authors [35] found that the optimized condition for okra osmotic dehydration was : sucrose concentration, 49.28(\% w/w); solution temperature, $40.79{ }^{\circ} \mathrm{C}$; sample size diameter, $15 \mathrm{~mm}$ and process time, $4.49 \mathrm{hrs}$. At this optimized condition, water loss and solute gain of $39.78 \%$ and $10.16 \%$ respectively were observed. Other authors [36] have also tested two levels of sucrose concentrated solution (40 and $60^{\circ}$ Brix) to pretreat sliced $(7 \mathrm{~mm})$ okra (Abelmoschus caillei) before drying in a convective dryer at temperatures ranging from 50 to $80^{\circ} \mathrm{C}$. The quality attributes investigated were only: ash content, crude fiber, crude fat, crude protein, bulk density, least gelation concentration and water absorption capacity. In their work, no result is given on the weight reduction and on the solute gain. For the sets of authors [35] and [36], there is no information on the final physical presentation of the product in the market and on the local tastes; that is the acceptability of sweet okra by the local population. Furthermore, they didn't carry out blanching of okra samples.

This work was therefore undertaken to study the behaviour of okra pods during the combined DISP/blanching and drying, with particular emphasis on the water absorption capacity of the fresh fruit and the influence of pre-treatment schedules prior to drying on the transfer kinetics and the product final appearance.

\section{Materials and Methods}

\subsection{Materials and Their Preparation}

Four morphologically distinct okra varieties (variety 1, 2, 3 and 4) collected in the locality of Ngaoundere in the Adamawa region of Cameroon were used (Figure 1), with variety 2 being the most cultivated. These varieties were different with respect to their colour (Figure 1), average fruit dimensions, weight and initial moisture content (Table 1). Fresh okra fruits were harvested at maturity from the corresponding okra plant early in the morning, using a sharp knife while leaving a $2-3 \mathrm{~cm}$ long stalk attached to the pods, put into cartons and promptly transported to the laboratory where they were washed with tap water and drained. Using a razor blade, the stalk was reduced to $1 \mathrm{~cm}$ and the sepal whorls hand-removed. Pods with wounds and bruises were discarded and the rest were measured (pod length, diameter using a Mitutoyo digital caliper) and weighed.

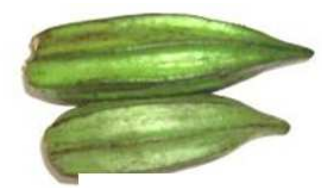

(1)

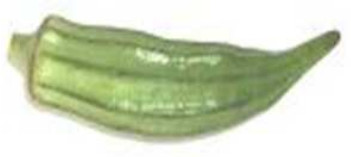

(3)

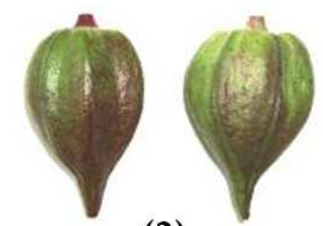

(2)

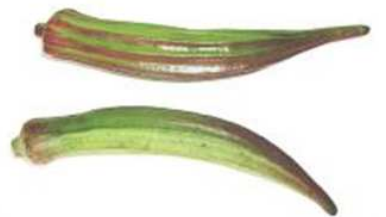

(4)
Figure 1. Morphology of the various okra varieties studied: varieties 1, 2, 3 and 4.

Table 1. Physical characterization of okra varieties. Values are means \pm standard deviations of measurements from 50 fruits.

\begin{tabular}{lllll}
\hline Variety Length (cm) & Diameter (cm) & Weight $(\mathrm{g})$ & Moisture (w-b) (\%) \\
\hline 1 & $8.0 \pm 0.5$ & $3.5 \pm 0.2$ & $29.0 \pm 2.0$ & 89.2 \\
2 & $8.0 \pm 0.3$ & $3.0 \pm 0.2$ & $18.0 \pm 1.0$ & 91.2 \\
3 & $6.5 \pm 0.3$ & $1.6 \pm 0.1$ & $10.0 \pm 0.5$ & 90.2 \\
4 & $12.0 \pm 2.1$ & $1.5 \pm 0.1$ & $17.5 \pm 1.1$ & 88.2 \\
\hline
\end{tabular}

Fresh okra when stored under ambient conditions (22 $25^{\circ} \mathrm{C}$ and $75-80 \%$ relative humidity) exchanged matter with the atmosphere, resulting in about $9 \%$ and $16 \%$ weight loss after $12 \mathrm{hrs}$ and $24 \mathrm{hrs}$ of storage, respectively. No appreciable differences were observed following storage for less than 3 hrs. Hence, the duration between harvesting and treatment of fruits was reduced to a maximum of $3 \mathrm{hrs}$.

Other materials used to prepare the osmotic solution included AnalaR grade ascorbic acid and citric acid, as well as food grade commercial sodium chloride (common salt) and calcium montmorillonite clay locally known as "Kanwa".

\subsection{Evaluation of the Water Absorption Capacity of Fresh Okra Fruits}

The evaluation of the water absorption capacity of okra fruits was conducted in hot water $\left(85^{\circ} \mathrm{C}\right)$. This involved immersing the fruits into the hot water, and allowing the whole to cool to room temperature $\left(24^{\circ} \mathrm{C}\right)$ over a $48 \mathrm{hrs}$ period. Okras cut into slices $(\sim 0.5 \mathrm{~cm})$ and uncut okras were studied. The water gain (WG) was calculated as shown in section 2.5. Each experiment was run in triplicate. 


\subsection{Pre-Treatment of Okra Fruits}

The cleaned okra fruits were subjected to either drying without any pre-treatment, or blanching in hot water prior to drying, or subjected to a combined dewatering-impregnationsoaking process/blanching in salt solution $(30 \mathrm{~g} / 100 \mathrm{~g})$ before drying. Each experiment was run in triplicate.

Temperature range of simple blanching in the literature is between $65^{\circ} \mathrm{C}$ to $100^{\circ} \mathrm{C}$ with process time varying between $15 \mathrm{sec}$ to 45 minutes $[27,30]$. Based on the literature results, our experiment was carried out with three blanching schedules in order to compare their effectiveness: $100^{\circ} \mathrm{C}$ for $5 \mathrm{~s}, 100^{\circ} \mathrm{C}$ for $10 \mathrm{~s}$, and $90^{\circ} \mathrm{C}$ for $1 \mathrm{~min}$. The blanching consisted of dipping the fresh fruits into hot water (with a mass ratio fruit to water of $1: 8$ ) at a predefined temperature and duration, to deactivate and/or destroy all enzymes present while modifying the physical and chemical properties of the fruits. For a given blanching temperature, the fruits were dipped into the hot water using plastic sieve spoons. Once the blanching duration had been exhausted, the spoons were retrieved and the pods were gently rubbed with absorbent tissue, weighed and dried.

The combined process (DISP/blanching) used has been described in detail elsewhere [29]. It consists of immersing the okra fruits into a warm $\left(85^{\circ} \mathrm{C}\right)$ osmotic solution $(\mathrm{pH} 6.5)$ and the whole allowed to cool to room temperature $\left(\sim 24^{\circ} \mathrm{C}\right)$. The behaviour of uncut and cut okras (slices) was studied. The osmotic solution was composed of water / common salt / ascorbic acid / citric acid / "kanwa" in ratio (w/w) 100:30:1:1:5. The choice of the concentrated solution was based on literature review and on the popular okra diets which are usually salted $[3,21]$. The solution was regularly stirred (every hour) until the end of the experiment. Then, the pods were removed from solution, rubbed gently with absorbent tissue and promptly introduced into the convective dryer. The ratio fruit to solution of 1:8 (w/w) was maintained throughout the DISP.

\subsection{Drying of Okra Samples}

The pre-treated okra pods were placed on a grilled nylon mesh and introduced into a convective dryer at $40^{\circ} \mathrm{C}$, with no-recycling of the hot air. This drying temperature has been shown to be suitable for okra and some leafy vegetable [27, $37,38]$. The relative humidity of the air was estimated using wet and dry bulb thermometers.

During the drying process and on a regular basis, okra samples were retrieved from the oven, rapidly weighed and then returned into the dryer. The drying process ended at a time supposed to be enough to make comparisons between the different processes investigated. Each experiment was run in triplicate.

\subsection{Calculations}

Water loss, weight reduction, solute gain and water gain during soaking processes relatively to product initial mass were calculated using the following expressions [29]:

$$
\begin{gathered}
W L(t)=\frac{M_{w}(0)-M_{w}(t)}{M_{p}(0)} \\
W R(t)=\frac{M_{p}(0)-M_{p}(t)}{M_{p}(0)} \\
S G(t)=\frac{M_{p}(t) \cdot M S(t)-M_{p}(0) \cdot M S(0)}{M_{p}(0)} \\
W G(t)=\frac{M_{w}(t)-M_{w}(0)}{M_{p}(0)}=-W L(t)
\end{gathered}
$$

We also have:

$$
\mathrm{WL}(\mathrm{t})=\mathrm{WR}(\mathrm{t})+\mathrm{SG}(\mathrm{t})
$$

With:

$\mathrm{t}$ : Time (sec)

$\mathrm{WL}(\mathrm{t})$ : Water loss at time $\mathrm{t}$, relatively to product initial $\operatorname{mass}(\mathrm{g} / \mathrm{g})$

$M_{w}(t)$ : Mass of water at time $t(g)$

$\mathrm{M}_{\mathrm{p}}(\mathrm{t})$ : Mass of product at time $\mathrm{t}(\mathrm{g})$

$\mathrm{WR}(\mathrm{t})$ : Weight Reduction at time $\mathrm{t}$, relatively to product initial mass $(\mathrm{g} / \mathrm{g})$

$\mathrm{SG}(\mathrm{t})$ : Solute Gain at time $\mathrm{t}$, relatively to product initial $\operatorname{mass}(\mathrm{g} / \mathrm{g})$

WG $(t)$ : Water gain at time $t$, relatively to product initial $\operatorname{mass}(\mathrm{g} / \mathrm{g})$

$\mathrm{MS}(\mathrm{t})$ : Dry matter content (wet basis) at time $\mathrm{t}(\mathrm{g} / \mathrm{g})$, determined using a standard technique [39]

$\mathrm{X}(\mathrm{t})$ is the product moisture content at time $\mathrm{t}(\mathrm{g} / 100 \mathrm{~g} \mathrm{~d}-\mathrm{b})$.

When water loss or weight reduction is negative, it means that there is respectively a water gain or a gain in weight rather than a loss.

Changes in the volume of okra fruit during drying were equally monitored. The volume of each fruit (fresh or dried) was estimated by submerging the fruit in water contained in a measuring cylinder. The difference between the initial volume $\left(\mathrm{V}_{\mathrm{i}}\right)$ and the final volume $\left(\mathrm{V}_{\mathrm{f}}\right)$ gave the shrinkage in volume. The shrinkage ratio was then calculated as follows:

$$
\text { Shrinkage }(\%)=\left[\frac{\left(V_{i}-V_{f}\right)}{V_{i}}\right] \cdot 100
$$

\section{Results and Discussion}

\subsection{The Behaviour of Okras During Soaking in Solutions}

\subsubsection{The Behaviour of Okras in Hot Water}

The kinetics of water gain during the immersion process, in water at $85^{\circ} \mathrm{C}$ and allowed to cool till room temperature are presented in Figure 2. This figure shows that the okra absorbs water with a concomitant increase of its mass. The absorption capacity increases progressively from the onset of immersion to a maximum after about $34 \mathrm{hrs}$ for whole okra fruits. The maximum absorption capacities of whole okra are presented in table 2. Okra varieties present different water absorbing capacities, probably due to differences in their specific surface areas (area per unit weight). 
Among the four okra varieties tested, variety 2 in its whole form is the one presenting the lowest maximum water absorption capacity. Therefore, the study of the behaviour of sliced forms was done using variety 2 only. When cut into slices, the fruits absorb water much more rapidly, with an initial rate $(0.11 \mathrm{~kg} / \mathrm{kg} / \mathrm{s})$ that is about five times the one obtained with the whole form. The maximum absorption capacity for the sliced okra is reached in just $4 \mathrm{hrs}$ compared to the $34 \mathrm{hrs}$ for the whole okra fruits. For variety 2, the corresponding maximum water gains are respectively $24.8 \%$ and $105.2 \%$ (Table 2). These peaks should coincide with their respective saturation points when the plant tissues could no longer contain absorbed water. These results could be linked to the surface structures and porosities of these materials.

This high water absorbing capacity of okra could therefore justify its classification as a thickener as proposed by [8].

Table 2. Maximum absorption capacity (in \%) of whole and sliced okras.

\begin{tabular}{|c|c|c|c|c|}
\hline & Whole & & & Slices \\
\hline Variety 1 & Variety 2 & Variety 3 & Variety 4 & Variety 2 \\
\hline $30 \%$ & $24,8 \%$ & $38,0 \%$ & $29,2 \%$ & $105,2 \%$ \\
\hline
\end{tabular}
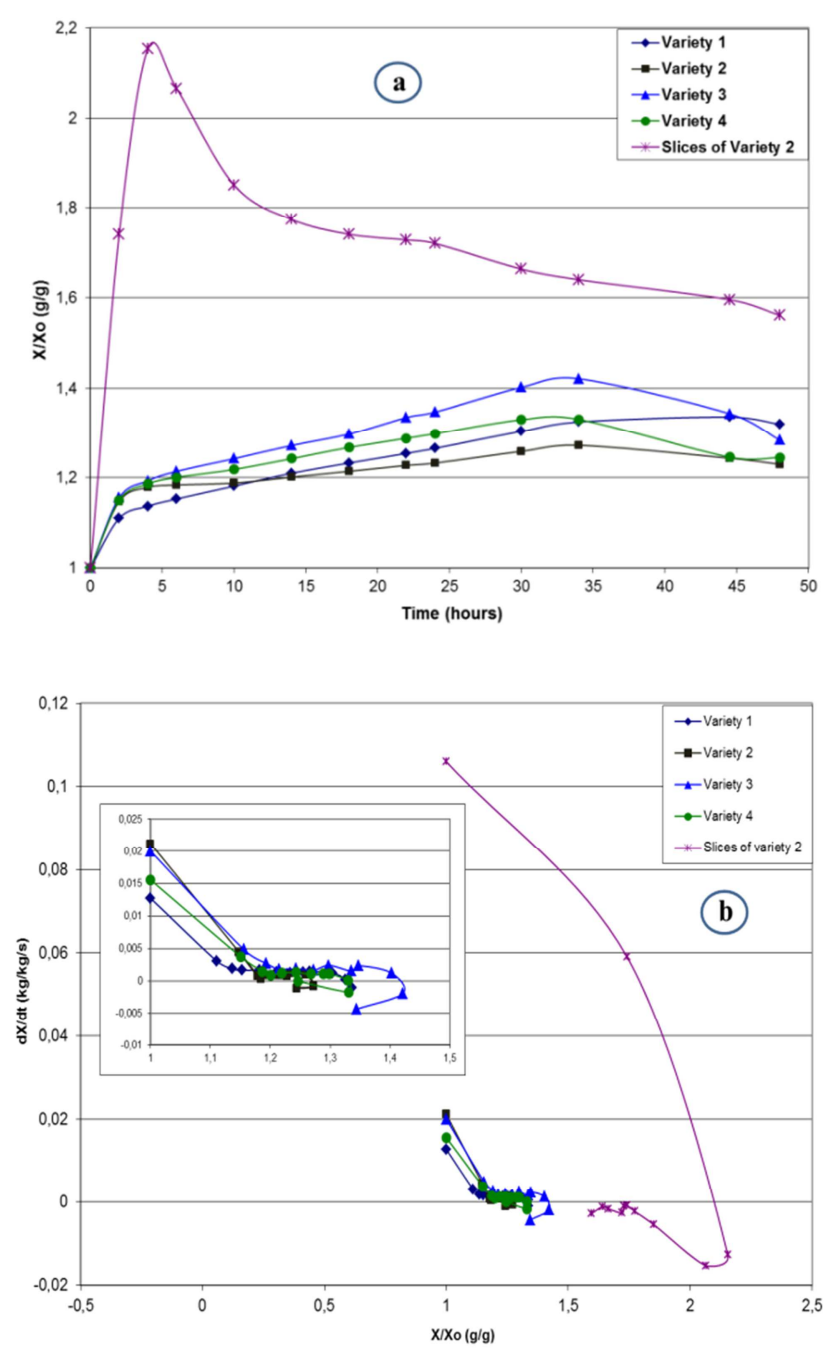

Figure 2. Kinetics of water gain (a) and Water absorption rate (b) of okras during soaking in simple hot water.
After the peaks, the okra fruits progressively lost weight, a phenomenon that was more pronounced for the sliced okra. This could be considered as due to mucilage (gum) dissociation and diffusion into solution. These molecules should mostly involve water-soluble polysaccharides like rhamnose and galacturonic acid often reported to be associated with proteins $[2,9]$. From the peak value to the end of soaking (after $48 \mathrm{hrs}$ ), material losses for the sliced and whole fruits of variety 2 were respectively $26.3 \%$ and $3.1 \%$, relatively to the peak values. Over this time slot, figures 2 (a) and (b) are drawn considering constant dry mass of samples.

\subsubsection{The Behaviour of Okras in Concentrated Solutions}

Trials to understand okra behaviour in concentrated solutions were carried out with the variety 2 fruits. Okras cut into slices $(\sim 0.5 \mathrm{~cm})$ and uncut okras were studied. The results collected after $12 \mathrm{hrs}$ and after $24 \mathrm{hrs}$ soaking in concentrated solutions $\left(85^{\circ} \mathrm{C}\right.$ to ambient temperature) are presented on figure 3. They are compared to the results obtained for the same times while soaking fruits of the same variety in simple hot water $\left(85^{\circ} \mathrm{C}\right.$ to ambient temperature).
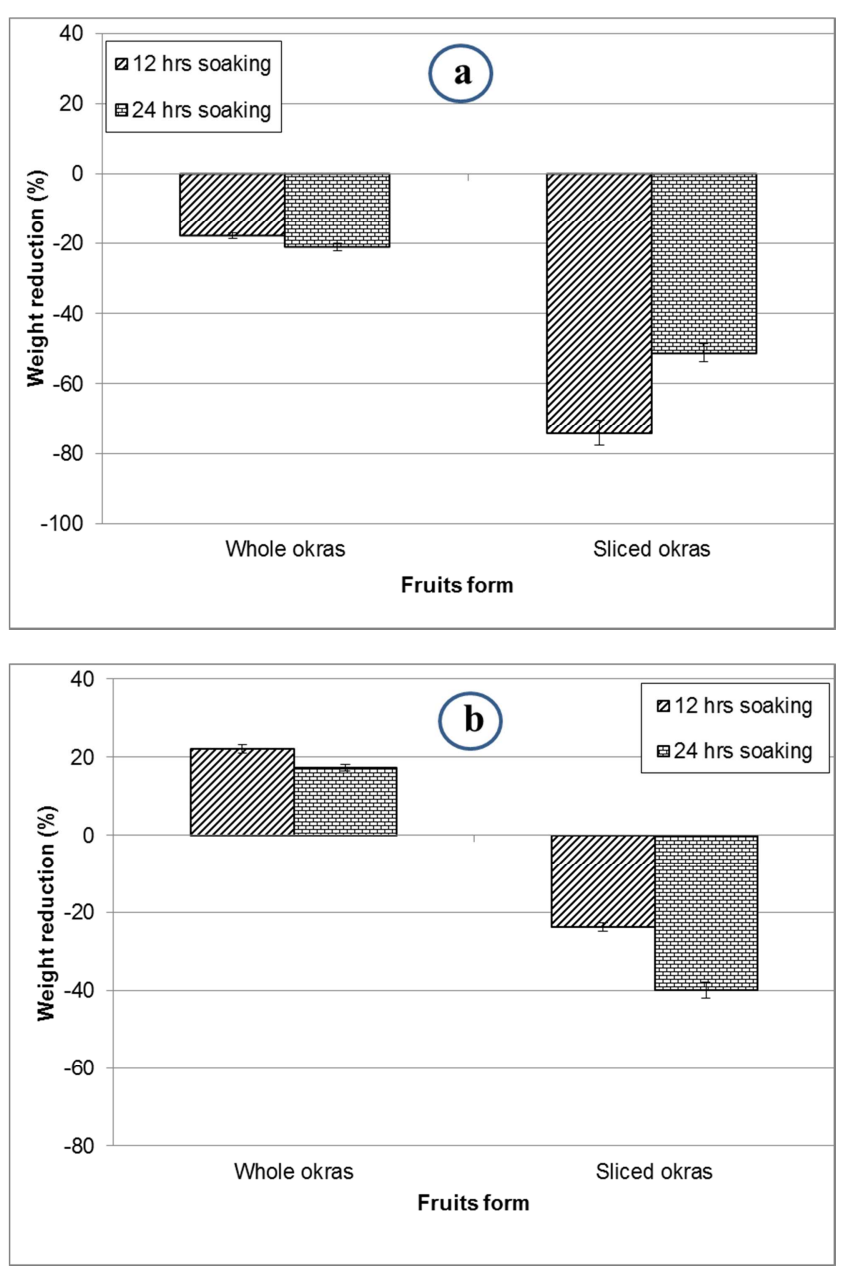

Figure 3. Weight reduction (in \%) of okra (variety 2) soaked in different solutions dropping from $85^{\circ} \mathrm{C}$ to ambient temperature: simple hot water (a) and $\mathrm{NaCl}$ solution (30g/100g) (b).

Figure 3 shows that, in sodium chloride concentrated 
solution, okra undergoes dehydration only in its entire form. The weight reductions registered are then $22.1 \%$ and $17.3 \%$ at the end of 12 and $24 \mathrm{hrs}$ soaking respectively. This implies that between 12 and $24 \mathrm{hrs}$ of soaking, the solute gain became more significant than the water loss.

In a salt solution of $30 \mathrm{~g} / 100 \mathrm{~g}$ of water, okras cut into slices $(\sim 0.5 \mathrm{~cm})$ absorb water as when soaked in simple hot water. In a salt solution, the weight gain is $23.8 \%$ at the end of $12 \mathrm{hrs}$ and $40.0 \%$ in average at the end of $24 \mathrm{hrs}$. A test adding to the concentrated solution "kanwa" or ascorbic acid at $5 \mathrm{~g} / 100 \mathrm{~g}$ and $1 \mathrm{~g} / 100 \mathrm{~g}$ concentration respectively didn't significantly affect the weight gains during soaking. These results show that sliced okras whether in concentrated solutions or not, undergo a mass increase. This phenomenon could result from the fact that, damaged plant tissues release into solution their mucilage contents, whose interaction with water get it inflated in proportion to the water it is able to absorb. These results are opposite to those obtained by [35] working on osmotic dehydration of sliced okra in sucrose solution. The differences obtained could be explained by the absence of blanching procedure in their method, the variety of okra, the type of the dipping solution or the operating conditions.

Using okra in its cut form equally presents the inconvenience of seeds found in solution. Many authors have shown the potential of okra seed as rich sources of edible fat and protein $[12,13]$. Therefore, the treatment of okra in its sliced form reduces its nutritive value if all its elements are not collected at the end of the treatment.

Taking into account these results, further treatments on okra were exclusively conducted using okra in its whole form.

\subsection{Convective Drying}

Drying was conducted at $40^{\circ} \mathrm{C}$ either directly on okra pods without treatment or after two different pre-treatments: simple blanching and the combined DISP/Blanching process. The ambient air temperature was $24^{\circ} \mathrm{C}$ in average and the relative humidity was between 75 and $80 \%$.

\subsubsection{The Behaviour of Okra Pods During Simple Drying}

Okra pods of the four varieties, freshly harvested, were introduced into the convective dryer. The drying kinetics results obtained are presented on figure 4. It appears that the four okra varieties behave differently during simple drying. The obtained mass transfer rate of variety 3 is greater than those of the three other varieties. It is then followed by variety 2 , variety 4 and finally variety 1 . The differences observed are largely dependent on the size of the fruits tested and on the okra's variety. Variety 3 has the smallest size of fruits tested. It is therefore advisable not to dry fruits of different varieties or sizes in the same drier to avoid heterogeneity on treated products. Moreover, from global perspectives, drying untreated okras is time demanding, more than 4 days of constant drying, respecting our drying conditions.
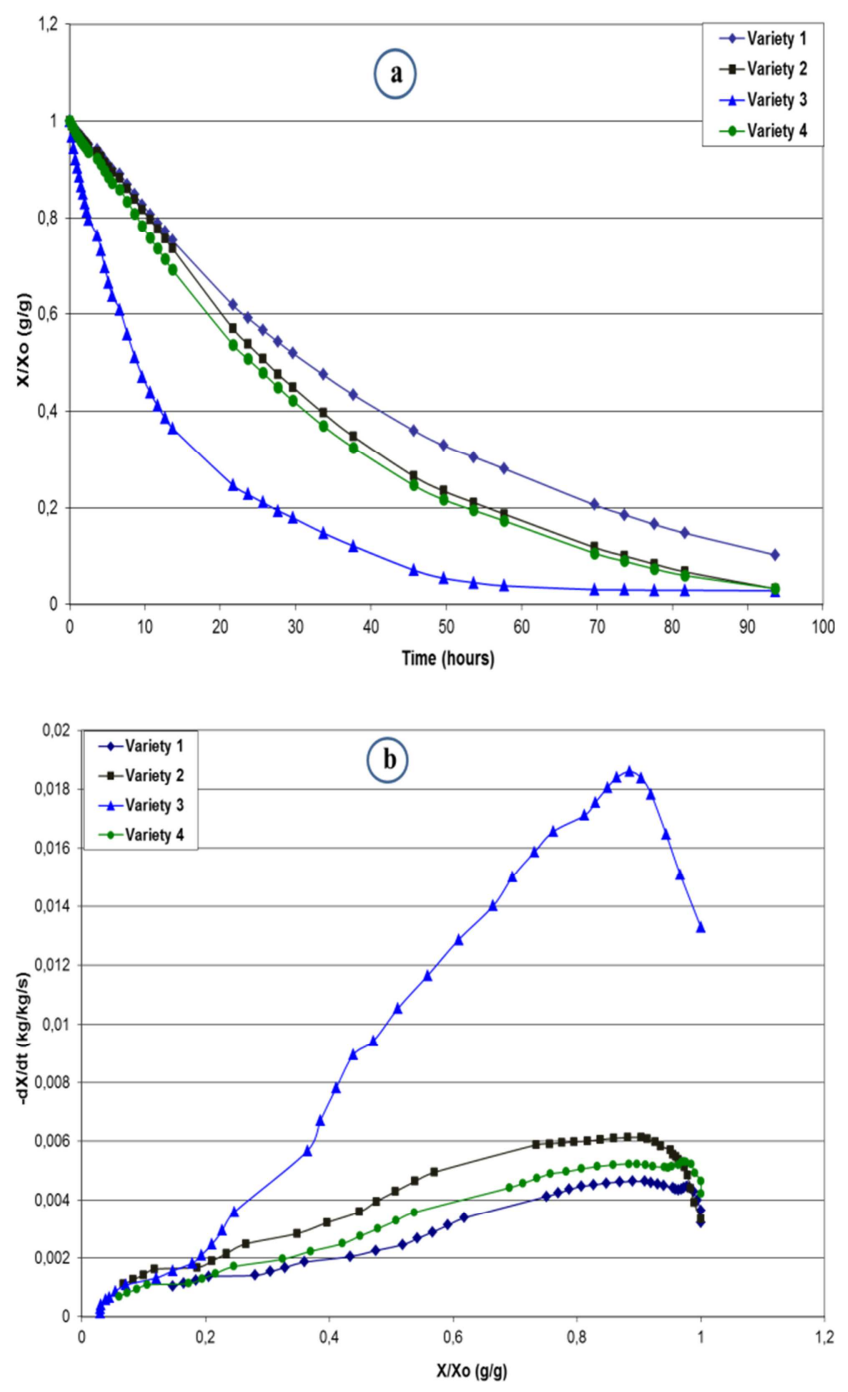

Figure 4. Influence of okra variety on transfer kinetics (a) and on transfer rate (b) during drying at $40^{\circ} \mathrm{C}$.

From visual inspection after 93 hrs drying, the colours of the dried okras were not up to our expectations and mindful of the fact that some pre-treatments play a genuine role in ameliorating these colorations, it was then necessary to proceed with pre-treatments which could bring a change.

To rectify these unfavourable economic factors, a pretreatment which consists in blanching our okra pods was carried out.

\subsubsection{Drying of Blanched Okras}

\section{(i). Influence of Blanching Schedules}

Experiments were carried out using variety 2, with three blanching schedules: $100^{\circ} \mathrm{C}$ for $5 \mathrm{~s}, 100^{\circ} \mathrm{C}$ for $10 \mathrm{~s}$, and $90^{\circ} \mathrm{C}$ for $1 \mathrm{~min}$. Figure 5 presents the drying kinetics obtained.

A measurement of shrinkage, which is their reductions in volume, was also carried out after drying. These results are reported on figure 6 and show that the greatest value of shrinkage is obtained when okras are blanched for $1 \mathrm{~min}$ at $90^{\circ} \mathrm{C}$. 

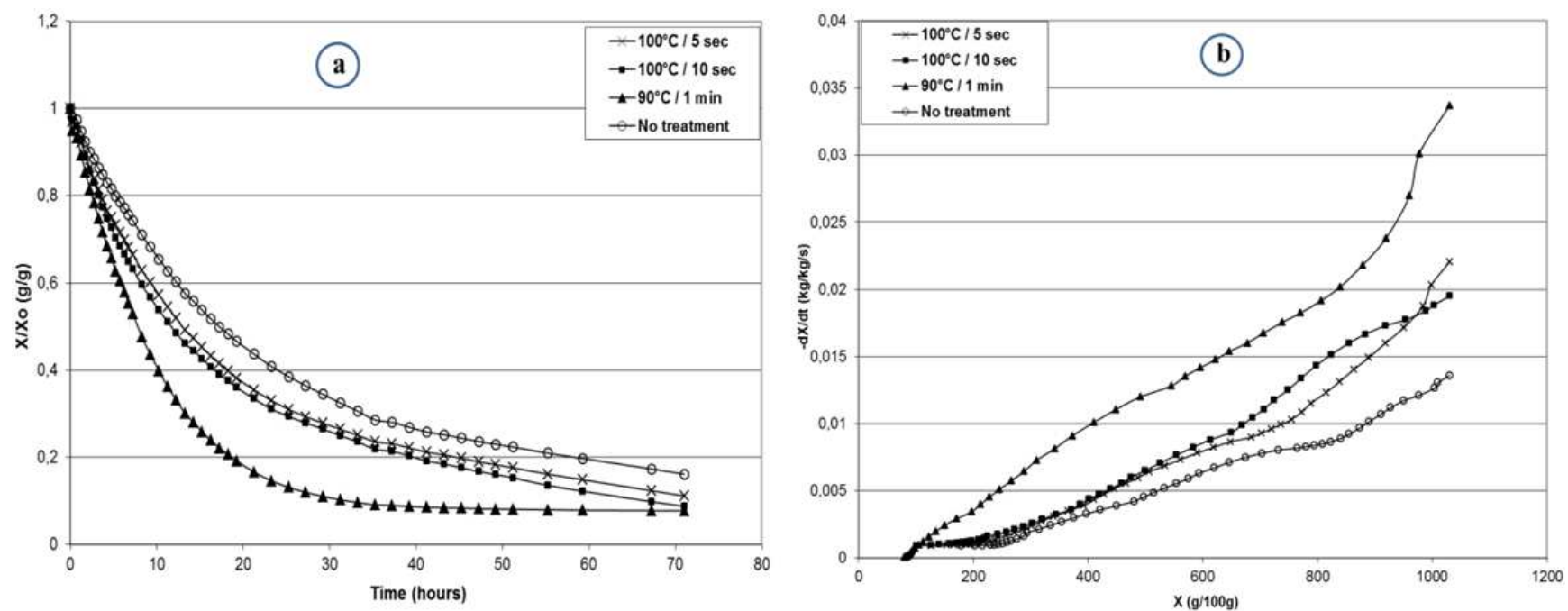

Figure 5. Influence of blanching schedules on transfer kinetics (a) and on transfer rate (b).

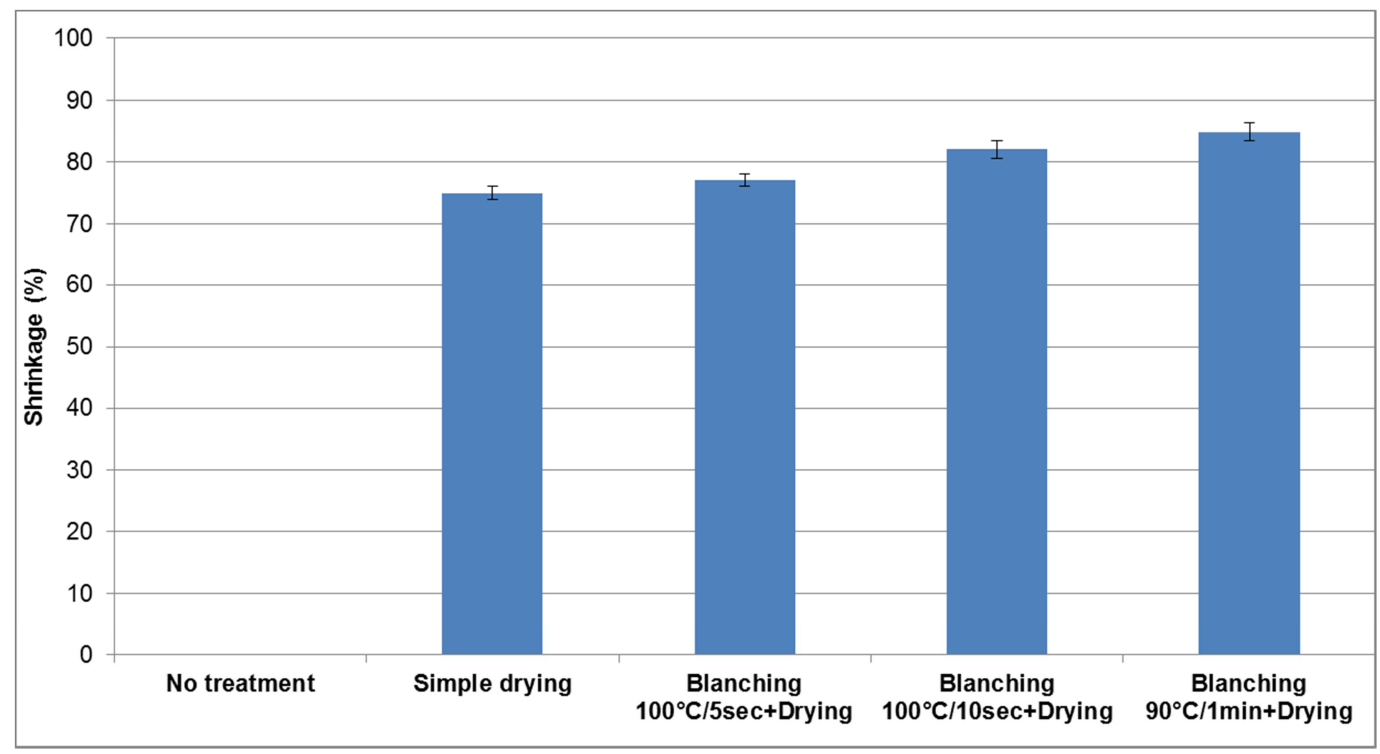

Figure 6. Shrinkage phenomena of blanched okras compared to the one obtained with simple dried okras.

On a general note, we remarked that blanched okras dried faster than non-treated okras. Thus, blanching treatments accelerate the drying of the humid products, in the sense that they reduce the duration of drying. Moreover, increasing the time for blanching has the impact of reducing the duration of drying. The drying of blanched okras follows a trend of the order $1 \min >>10 \mathrm{~s}>5 \mathrm{~s}>$ non-treated.

After 40 hrs drying, okras blanched for $1 \mathrm{~min}$ at $90^{\circ} \mathrm{C}$ were already stable whereas, untreated okras required more than 30 additional hours for a complete drying under the same conditions.

For this variety 2 okra, the colour changed from its greenreddish into a pronounced brown colour, which appeared a few minutes after blanching and which eventually turned dark brown to black. This behaviour reoccurred for other trials and even when "kanwa" or ascorbic acid was used in pre-treating solution, implying that, no matter the blanching schedule used, the same results were obtained. Chlorophyll was always destroyed. Some authors [7] related that chlorophyll degradation in plant tissues with loss of green colour can be linked to the formation of brown pheophytin pigment. Furthermore, other authors [27] reveal contradictory reports on the effect of blanching on vegetable colour. Their works have shown that loss of chlorophyll in leafy vegetables during blanching necessitates a proper combination of time and temperature for blanching. Moreover, according to some [31], blanching of vegetables though makes green leafy vegetables more palatable and less toxic; however it reduces their antioxidant properties drastically.

Taking these into account, we thought it wise to treat our okras with a blanching schedule which was quite short to avoid nutrient loss and which equally guarantees us a short drying process. Hence, a compromise between the nutritional value and the drying duration of blanched okras led us to choose the blanching schedule for $10 \mathrm{~s}$ at $100^{\circ} \mathrm{C}$ as the most adequate schedule for further manipulations. This blanching 
schedule was adopted to treat the four okra varieties, whose drying kinetics are represented on figures $7 \mathrm{a}$ and $7 \mathrm{~b}$.
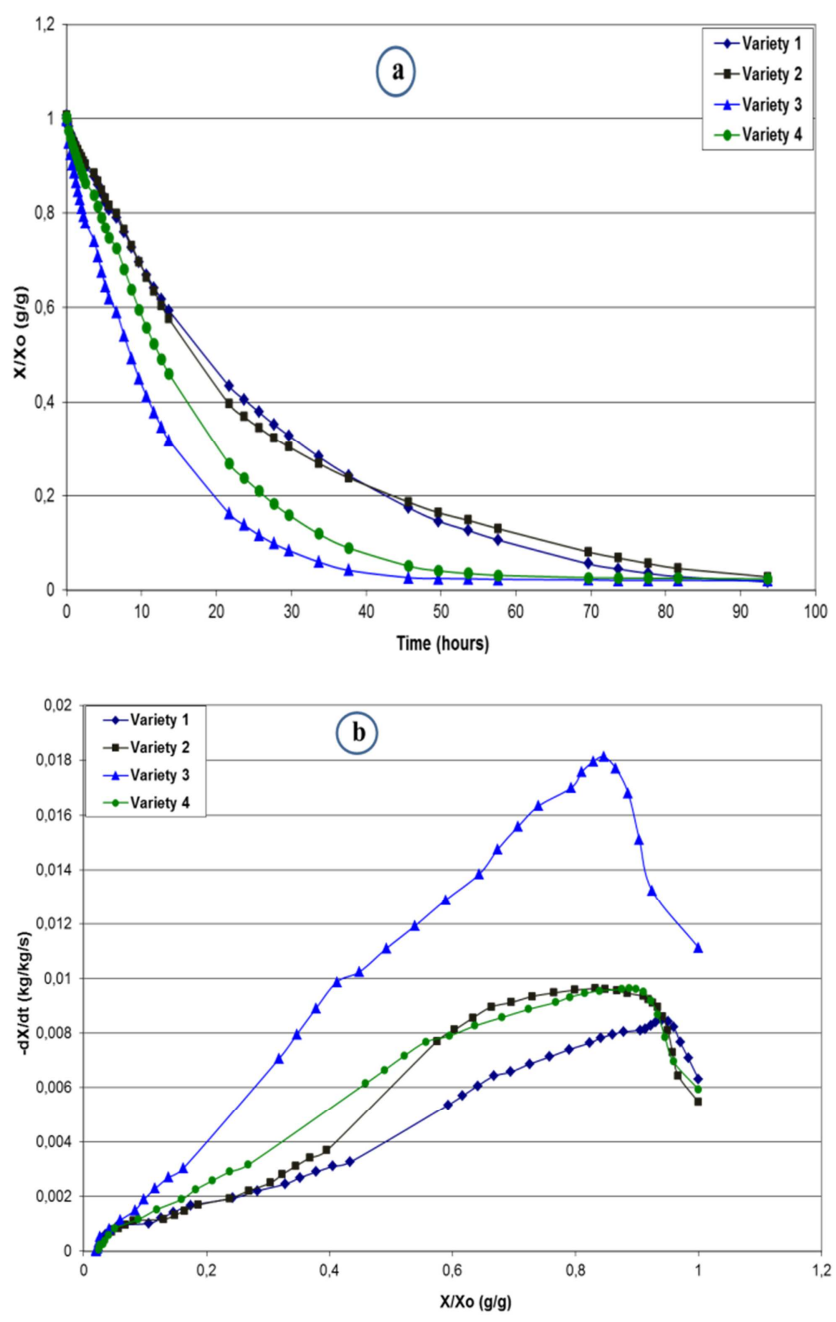

Figure 7. Mass transfer kinetics (a) and transfer rate (b) of blanched $\left(100^{\circ} \mathrm{C} / 10 \mathrm{~s}\right)$ okra varieties during drying at $40^{\circ} \mathrm{C}$.

The blanching procedure reduces drying time by about 20 hrs relatively to non-treated okras. Under the same conditions the drying trend of okra varieties was in the order: variety $3>$ variety $4>$ variety $2>$ variety 1 . This result can be linked to okra diameters and explains the radial transfers. The smaller the okra diameter, the higher the transfer rate. Dry mass for blanched okras remained unaffected, implying that blanching was only a propagating factor to water loss.

Furthermore, the observed unattractive colour of variety 2 underwent no colour modifications; however, the colour appearances of the other varieties were much better than that of variety 2 .

\section{(ii). Trials to Ameliorate the Colour Properties of Okras}

Blanching trials, with or without the presence of simple or mixed solutions of sodium chloride, "kanwa", sodium bicarbonate and citric acid were carried out. The fruit colours were visually appreciated. Among the four okra varieties studied, only variety 2 was reluctant to undergo any colour modifications. No matter the treatment applied, its colour was always brown after treatments.

For the other three varieties 1, 3 and 4, a solution containing sodium chloride, "kanwa", ascorbic acid, gave the best results in terms of colour. The concentrations retained for $100 \mathrm{~g}$ of water were $30 \mathrm{~g}$ of salt, $5 \mathrm{~g}$ of " $k a n w a$ " and $1 \mathrm{~g}$ of ascorbic acid. The $\mathrm{pH}$ of the solution was maintained at 6.5 with the help of citric acid. These concentrations were then adopted for use in the combined DISP/Blanching of okras.

\subsubsection{Drying of Okras Treated by the Combined DISP/Blanching}

A DISP/blanching experiment was conducted using the four okra varieties in their whole forms, soaked in the previously selected DISP solution, having a starting temperature of $85^{\circ} \mathrm{C}$ falling progressively to room temperature (about $24^{\circ} \mathrm{C}$ ). A summary of the results obtained after DISP/blanching are presented on table 3 . The DISP lasted $12 \mathrm{hrs}$.

Table 3. Combined DISP/Blanching of okras in salt solution $(30 \mathrm{~g} / 100 \mathrm{~g}$ at $85^{\circ} \mathrm{C}$ till room temperature): weight reduction, solute gain, water loss and final moisture content (d-b) obtained after 12 hrs of DISP/Blanching.

\begin{tabular}{lllll}
\hline Variety & $\begin{array}{l}\text { Weight Reduction } \\
(\mathbf{\%} \text { w/w })\end{array}$ & $\begin{array}{l}\text { Solute Gain } \\
(\mathbf{\%} \text { w/w) }\end{array}$ & $\begin{array}{l}\text { Water Loss } \\
(\mathbf{\%} \text { w/w) }\end{array}$ & X (g/100g) \\
\hline 1 & 18.6 & 8.8 & 27.4 & 411.0 \\
2 & 22.1 & 7.8 & 29.9 & 500.6 \\
3 & 16.6 & 9.8 & 26.4 & 410.7 \\
4 & 30.3 & 9.9 & 40.2 & 359.8 \\
\hline
\end{tabular}

Values represent means of triplicate calculations. Standard deviation on each value was less than $5 \%$.

Trials confirmed the dehydration of okra pods in their whole forms. We also noticed a solute intake which could help for conservation means. As shown on table 3, the varieties 1, 2 and 3 , were alike in their behaviour and equally presented an average weight reduction of $19.1 \%$ as against $30.3 \%$ for variety 4 . The corresponding average water loss was $27.9 \%$ for varieties 1, 2 and 3, versus $40.2 \%$ for variety 4 . It seems that the ability of dehydration of okra in salt solution depends on its water absorption capacity, i.e. on its polysaccharides content.

The DISP/Blanching was followed by the drying process in the convective dryer at $40^{\circ} \mathrm{C}$. Final results are presented on table 4 where values are given in percentage of the initial fresh product for weight reduction and water loss. Differences in tissues structure coupled to differences in okras' initial dimensions could account for the different behaviours observed on the four cultivars.

Table 4. Drying of DISP/Blanched okras at $40^{\circ} \mathrm{C}$ : weight reduction, solute gain, water loss and final water content (d-b) ratio obtained after $93.7 \mathrm{hrs}$ drying. $X_{0}$ is the final X obtained during previous DISP/Blanching (Table 3).

\begin{tabular}{lllll}
\hline Variety & $\begin{array}{l}\text { Weight Reduction } \\
(\% \mathbf{w} / \mathbf{w})\end{array}$ & $\begin{array}{l}\text { Solute Gain } \\
(\% \mathbf{w} / \mathbf{w})\end{array}$ & $\begin{array}{l}\text { Water Loss } \\
(\% \mathbf{w} / \mathbf{w})\end{array}$ & $\mathbf{X} / \mathbf{X}_{\mathbf{0}}$ \\
\hline 1 & 59.7 & 0 & 59.7 & 0.088 \\
2 & 59.4 & 0 & 59.4 & 0.085 \\
3 & 59.7 & 0 & 59.7 & 0.110 \\
4 & 46.0 & 0 & 46.0 & 0.157 \\
\hline
\end{tabular}

Values represent means of triplicate calculations. Standard deviation on each value was less than $5 \%$. 
In the course of the soaking process, varieties 1,3 and 4 retained correctly their colours while variety 2 lost its green colour to light brown. Then, during the drying process it was observed that as drying progressed, the residual salt $(\mathrm{NaCl})$ found on the surface of the pods also underwent drying and produced a whitish colour. This whitish appearance eventually suppressed the visibility of the other colours which were previously present. The dark brown colour of variety 2 fortunately, became masked by the whitish salt colour, giving it a greyish appearance, which in fact modified its colour presentation unlike before.
Table 5. Contribution (in percentage) of each process to total weight reduction, solute gain and water loss of the combined DISP/blanching and drying process.

\begin{tabular}{lllllll}
\hline $\begin{array}{l}\text { Contribution } \\
\text { to }\end{array}$ & Process & $\begin{array}{l}\text { Variety } \\
\mathbf{1}\end{array}$ & $\begin{array}{l}\text { Variety } \\
\mathbf{2}\end{array}$ & $\begin{array}{l}\text { Variety } \\
\mathbf{3}\end{array}$ & $\begin{array}{l}\text { Variety } \\
\mathbf{4}\end{array}$ & Average \\
\hline Weight & DISP & 23.8 & 27.1 & 21.8 & 39.7 & 28.1 \\
Reduction & Drying & 76.2 & 72.9 & 78.2 & 60.3 & 71.9 \\
\multirow{2}{*}{ Solute Gain } & DISP & 100 & 100 & 100 & 100 & 100 \\
& Drying & 0 & 0 & 0 & 0 & 0 \\
\multirow{2}{*}{ Water Loss } & DISP & 31.5 & 33.5 & 30.7 & 46.6 & 35.6 \\
& Drying & 68.5 & 66.5 & 69.3 & 53.4 & 64.4 \\
\hline
\end{tabular}
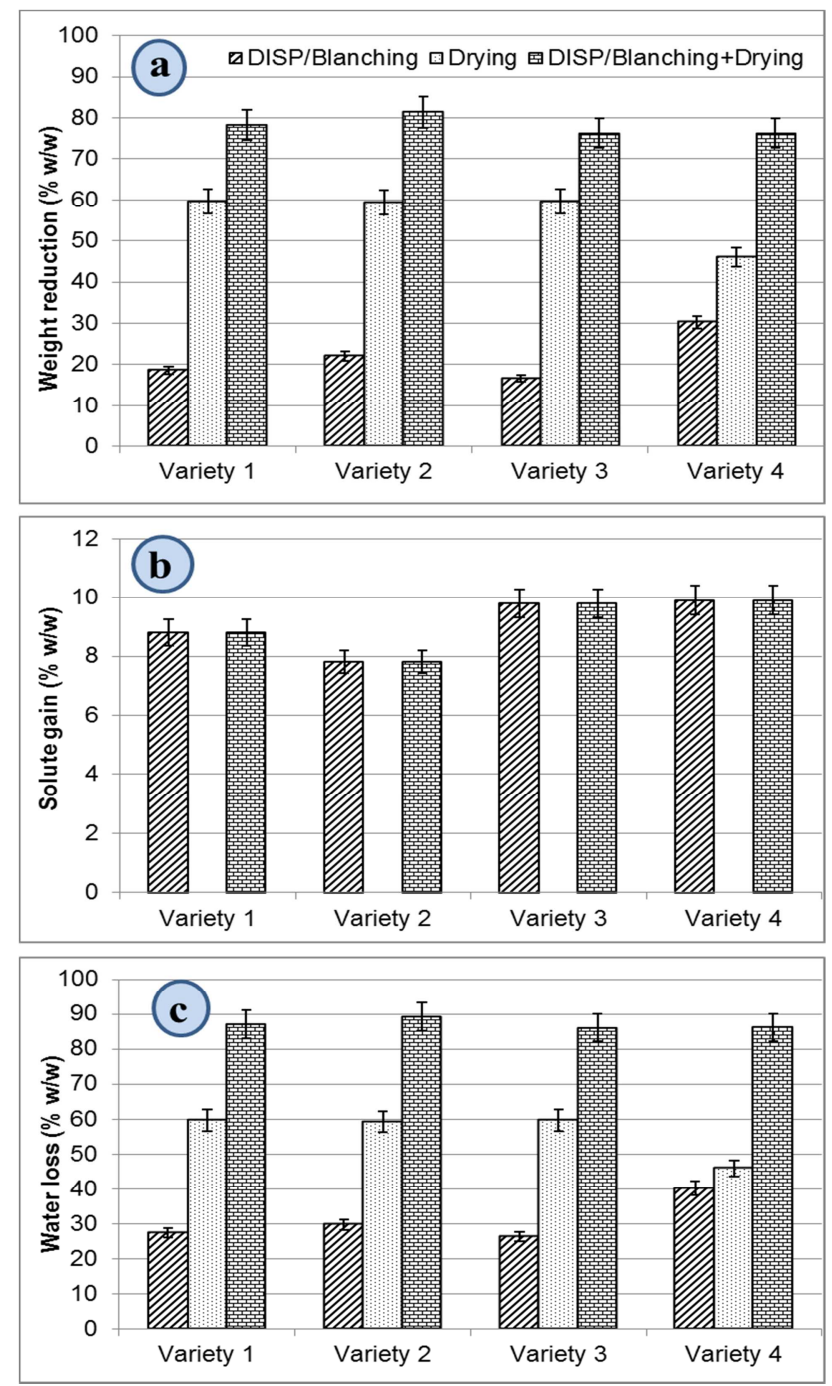

Figure 8. Okras weight reduction (a), solute gain (b) and water loss (c) during the combined DISP/Blanching and drying process.

The combined DISP/Blanching and drying of okra varieties gave averages of $(78.1 \pm 3.6) \%$ weight reduction, $(9.1 \pm 0.5) \%$ solute gain and $(87.2 \pm 4.0) \%$ water loss. Details are presented on figures $8 \mathrm{a}, 8 \mathrm{~b}$ and $8 \mathrm{c}$. Finally, the DISP/blanching process was responsible for $35.6 \%$ in average of moisture loss over the four okra varieties tested, while drying accounted for a $64.4 \%$ water loss as presented on table 5. These results reflected those of [29], working on tropical fruits. Nevertheless, it can be seen from results presented on table 4 that the moisture contents of the four okra varieties, treated in the whole form, remain high after $93.7 \mathrm{hrs}$ convective drying at $40^{\circ} \mathrm{C}$. The final moisture content (w-b) for the tested conditions is respectively 26.6, $29.8,31.1$ and $36.1 \%$ for varieties $1,2,3$ and 4 . The air drying conditions (relative humidity and velocity) as well as the load of the dryer could have an important effect on mass transfers as shown in several works [40-42].

\subsubsection{The Impacts of Preliminary Okras Treatments on Drying Kinetics}

On figure 9 is presented the drying rate of the four okra 
varieties, according to the preliminary treatment undergone. This figure shows that mass transfers during the process of drying DISP/Blanched okras is not too significant compared to those of blanched okras. This behaviour and the results
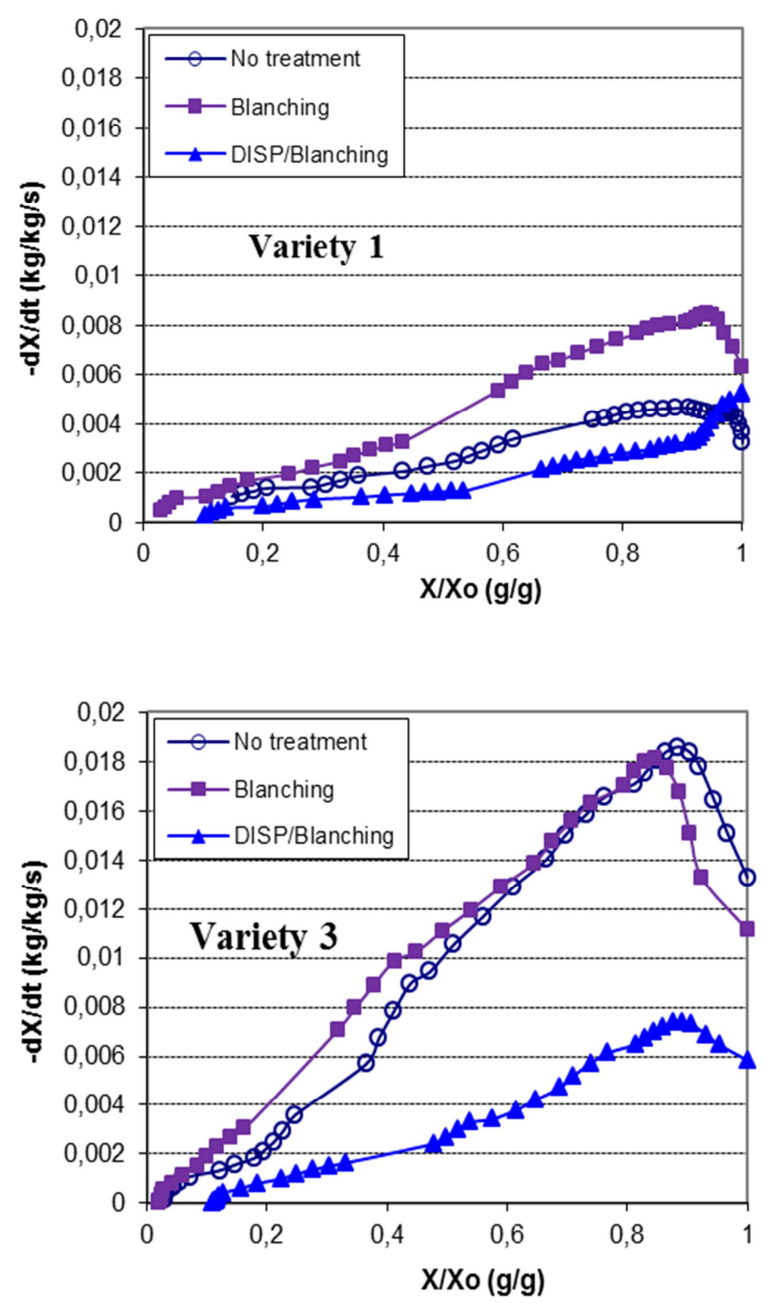

were not surprising because, the okra pods had previously undergone a water loss and a solute intake during the DISP/Blanching.
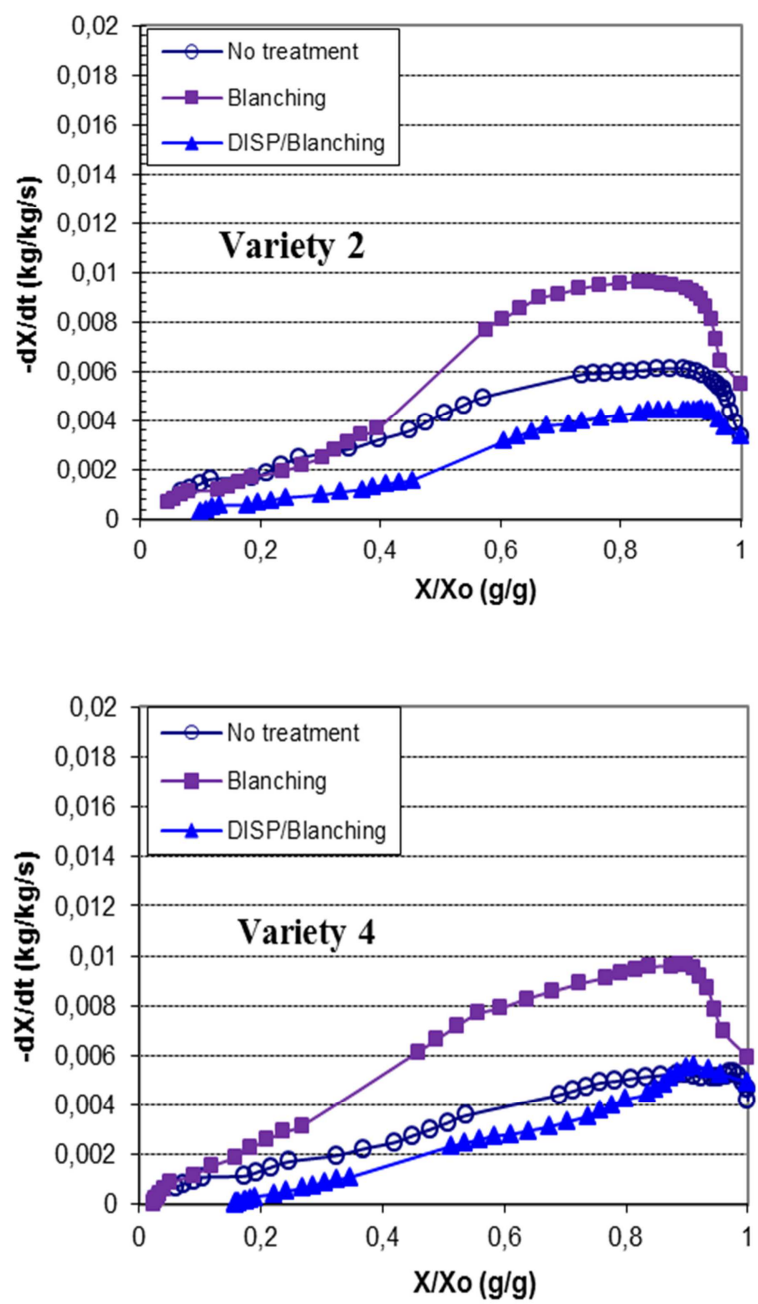

Figure 9. Drying rate of the four okra varieties: Impacts of the preliminary treatment (blanching or DISP/Blanching) compared to non-treated okras drying kinetics.

\section{Conclusions}

The effects of okra pre-treatments on drying kinetics and dried okra final presentation were studied. This work shows that it is possible to improve the dried okra final appearance using the coupled process DISP/Blanching and drying. Results obtained indicate that the only way to register a water loss in the sample during the DISP/Blanching, in a salt solution at $30 \mathrm{~g} / 100 \mathrm{~g}$ with a temperature falling progressively from $85^{\circ} \mathrm{C}$ to room temperature, is to soak the fruits in their whole forms. The advantage of this process resides on the solute intake $(9.1 \pm 0.5) \%$ that increases the preservation potentialities of the final product. The drying rates as well as the water loss and solute gains obtained show the importance of taking into account the variety and the size of okra during its treatment by the DISP/blanching and/or the drying processes.
This work is far from being exhaustive. A sensory analysis test on the final product is in project. Nevertheless a study on the possibility of valorising the osmotic dehydration solution and economic aspects should be taken into consideration as well.

\section{Acknowledgement}

The authors acknowledge the Process Engineering and Automatic Laboratory (LAGEP) of the University of Lyon 1France. They also thank The French Embassy in Cameroon for their financial support.

\section{References}

[1] Purseglove J. W, 1987. Tropical crops-dicotyledons. Edition Longman, New York, USA, 368-370. 
[2] Sengkhamparn Nipaporn, Verhoef R., Schols Henk A., Sajjaanantakul Tanaboon, Voragen Alphons G. J., 2009. Characterisation of cell wall polysaccharides from okra (Abelmoschus esculentus (L.) Moench). Carbohydrate Research 344, 1824-1832.

[3] Ngbede S. O., Ibekwe H. N., Okpara S. C., Adejumo L., 2014. An Overview of Okra Production, Processing, Marketing, Utilization and Constraints in Ayaragu in Ivo Local Government Area of Ebonyi State, Nigeria. Greener Journal of Agricultural Sciences. 4 (4), 136-143.

[4] Sedat Çalışır, Musa Özcan, Haydar Hacıseferoğulları and M. Uğur Yıldız, 2005. A study on some physico-chemical properties of Turkey okra (Hibiscus esculenta L.) seeds. Journal of Food Engineering, 68 (1), 73-78.

[5] Kumar S., Dagnoko S., Haougui A., Ratnadass A., Pasternak D. and Kouame C., 2010. Okra (Abelmoschus spp.) in West and Central Africa: Potential and progress on its improvement. African Journal of Agricultural Research, 5 (25), 3590-3598.

[6] Stansly P. A., Schuster D. J. and Tong-Xian Liu, 1997. Apparent Parasitism of Bemisia argentifolii (Homoptera: Aleyrodidae) by Aphelinidae (Hymenoptera) on Vegetable Crops and Associated Weeds in South Florida. Biological Control, 9 (1), 49-57.

[7] Adom K. K., Dzogbefia V. P., Ellis W. O. and Simpson B. K., 1996. Solar drying of okra: Effects of selected package materials on storage stability. Food Research International, 29 (7), 589-593.

[8] Ndjouenkeu R., Akingbala J. O. and Oguntimein G. B., 2005. Emulsifying properties of three African food hydrocolloids: okra (Hibiscus esculentus), dika nut (Irvingia gabonensis), and khan (Belschmiedia sp.) Journal of Food Science and Technology. 1-3.

[9] Deters A. M., Lengsfeld C. and Hensel A., 2005. Oligo-and polysaccharides exhibit a structure-dependent bioactivity on human keratinocytes in vitro. Journal of Ethnopharmacology, 102 (3), 391-399.

[10] Tilmon R. W. and Romanchik-Cerpovicz J. E., 2001. Feasibility of using okra exudate as a fat replacer in low fat chocolate dropped cookies. Journal of the American Dietetic Association, 101 (9), A23-A32.

[11] Romanchik-Cerpovicz J. E., Tilmon R. W. and Baldree K. A., 2002. Moisture Retention and Consumer Acceptability of Chocolate Bar Cookies Prepared With Okra Gum as a Fat Ingredient Substitute. Journal of the American Dietetic Association, 102 (9), 1301-1303.

[12] Savello P. A., Martins F. and Hull W., 1980. Nutrient composition of okra seed meals. Journal of Agriculture and Food Chemistry, 28 (6), 1163-1166.

[13] Oyelade O. J., Ade-Omowaye B. I. O. and Adeomi V. F., 2003. Influence of variety on protein, fat contents and some physical characteristics of okra seeds. Journal of Food Engineering, 57 (2), 111-114.

[14] Ijoyah M. O., Atanu S. O. and Ojo S., 2010. Productivity of okra (Abelmoschus esculentus L. Moench) at varying sowing dates in Makurdi, Nigeria. Journal of Applied Biosciences 32, 2015-2019.

[15] Konyeha, S., Alatise, M. O., 2013. Yield and Water Use of Okra (Abelmoschus esculentus L. Moench) under Water
Management Strategies in Akure, South-Western City of Nigeria. International Journal of Emerging Technology and Advanced Engineering, 3 (9), 8-12.

[16] Nwaobiala C. U. and Ogbonna M.O., 2014. Adoption Determinants and Profitability Analysis of Okra Farming In Aninri Local Government Area (LGA) of Enugu State, Nigeria. Discourse Journal of Agriculture and Food Sciences. www.resjournals.org/JAFS, 2 (1), 1-10.

[17] Mohammed A. Al-Sulaiman, 2011. Prediction of quality indices during drying of okra pods in a domestic microwave oven using artificial neural network model. African Journal of Agricultural Research Vol. 6(12), pp. 2680-2691.

[18] Olivera Daniela F., Mugridge Alicia, Chaves Alicia R., Mascheroni Rodolfo H. and Viña Sonia Z., 2012. Quality Attributes of Okra (Abelmoschus esculentus L. Moench) Pods as Affected by Cultivar and Fruit Size, Journal of Food Research, 1 (4), 224-235.

[19] Owolarafe O. K., Obayopo S. O., Obayopo S. O., Amarachi O. A., Babatunde O. and Ologunro O.A. 2011. Development and Performance Evaluation of an Okra Drying Machine. Research Journal of Applied Sciences, Engineering and Technology 3 (9), 914-922.

[20] Eke, Ben Akachukwu, 2013. Development of Small Scale Direct Mode Natural Convection Solar Dryer for Tomato, Okra and Carrot. International Journal of Engineering and Technology 3 (2). IJET Publications UK. 199-204.

[21] UNIDO, 2004. "Small-scale fruit and vegetable processing and products. Production methods, Equipment and quality assurance practices". UNIDO Technology Manual, United Nations Industrial Development Organization, Vienna, 106p.

[22] Arise A.K., Arise R.O., Akintola A.A., Idowu O.A. and Aworh O.C., 2012. Microbial, Nutritional and Sensory Evaluation of Traditional Sundried Okra (Orunla) in Selected Markets in South-Western Nigeria. Pakistan Journal of Nutrition 11 (3): 231-236. ISSN 1680-5194. Asian Network for Scientific Information.

[23] Adegbehingbe Kehinde Tope, 2014. Microbial analysis of sun-dried okra samples from some Akoko areas of Ondo state, Nigeria. IMPACT: International Journal of Research in Applied, Natural and Social Sciences (IMPACT: IJRANSS). 2 (5), 87-96.

[24] Shams El-Din M. H. A. and Shouk A. A., 1999. Comparative study between microwave and conventional dehydration of okra. Grasas y Aceites, 50 (6), 454-459.

[25] Aguilera J. M., Chiralt A. and Fito P., 2003. Food dehydration and product structure. Trends in Food Science and Technology, 14 (10), 432-437.

[26] Moreno J., Chiralt A., Escriche I. and Serra J. A., 2000. Effect of blanching/osmotic dehydration combined methods on quality and stability of minimally processed strawberries. Food Research International, 33 (7), 609-616.

[27] Negi P. S. and Roy S. K. 2000. Effect of Blanching and Drying Methods on $\beta$-Carotene, Ascorbic acid and Chlorophyll Retention of Leafy Vegetables. LebensmittelWissenschaft und-Technologie, 33 (4), 295-298.

[28] Jiokap Nono Y., Nuadje G. B., Raoult-Wack A.L. and Giroux F., 2001. Comportement de certains fruits tropicaux traités par déshydratation-imprégnation par immersion dans une solution de saccharose. Fruits, (France), 56 (2), 75-83. 
[29] Jiokap Nono Y., Reynes M., Zakhia N., Raoult-Wack A. L. and Giroux F., 2002. Mise au point d'un procédé combiné de déshydratation-imprégnation par immersion et séchage de bananes (Musa acuminata groupe cavendish). Journal of Food Engineering, 55, 231-236.

[30] Passo Tsamo C.V., Bilame A.-F., Ndjouenkeu R., Jiokap Nono Y., 2005. Study of material transfer during osmotic dehydration of onion slices (Allium cepa) and tomato fruits (Lycopersicon esculentum), Lebensmittel-Wissenschaft undTechnologie, 38: 495-500.

[31] Ganiyu Oboh, 2005. Effect of blanching on the antioxidant properties of some tropical green leafy vegetables. LWT Food Science and Technology, 38 (5), 513-517.

[32] Sotiriadis P. K. and Hoskins F. H., 1982. Vitamin retention during storage of processed foods. I. Effect of ascorbic acid on folates in cowpeas, okra and tomatoes. Scientia Horticulturae, $16(2), 125-130$.

[33] Aderiye B. I., 1985. Effects of ascorbic acid and prepackaging on shelf-life and quality of raw and cooked okra (Hibiscus esculentus). Food Chemistry, 16 (1), 69-77.

[34] Chen J. P., Tai C. Y. and Chen B. H., 2006. Effects of different drying treatments on the stability of carotenoids in Taiwanese mango (Mangifera indica L.). Food Chemistry, 100, 10051010 .

[35] Agarry S. E. and Owabor C. N., 2012. Statistical optimization of process variables for osmotic dehydration of okra (Abelmoschus esculentus) in sucrose solution. Nigerian Journal of Technology (NIJOTECH), 31 (3), 370-382.
[36] Olaniyan A. M. and Omoleyomi B. D., 2013. Characteristics of Okra under Different Process Pretreatments and Different Drying Conditions. Food Processing \& Technology, J Food Process Technol, 4:6. http://dx.doi.org/10.4172/21577110.1000237 .

[37] Wankhade P. K., Sapkal R. S. and Sapkal V. S., 2012. Drying Characteristics of Okra Slices using Different Drying Methods by Comparative Evaluation. Proceedings of the World Congress on Engineering and Computer Science, Vol II, WCECS 2012, October 24-26, San Francisco, USA.

[38] Famurewa J. A. V. and Olumofin K. M., 2015. Drying kinetics and influence on the chemical characteristics of dehydrated okra (Abelmoschus esculentus) using cabinet dryer. European Journal of Engineering and Technology, 3 (2), Progressive Academic Publishing, UK. www.idpublications.org. 7-19.

[39] AOAC (1980). Official methods of analysis, 13th ed., Association of Official Analytical Chemists, Washington D.C.

[40] Belghit A., Kouhila M., Boutaleb B. C., 1999. Experimental study of drying kinetics of sage in a drying tunnel working in forced convection. Rev. Energ. Ren. 2, 17-26.

[41] Tzempelikos D. A., Vouros A. P., Bardakas A. V., Filios A. E., Margaris D.P., 2014. Case Studies in Thermal Engineering, 3, 79-85.

[42] Taheri-Garavand A., Rafiee S. and Keyhani A., 2015. Effect of temperature, relative humidity and air velocity on drying kinetics and drying rate of basil leaves. Electronic Journal of Environmental, Agricultural and Food Chemistry, 10 (4), 2075-2080. 